\title{
Japan's project stalls
}

\section{Tokyo}

AmBitious plans by Japan's scientists to launch a human genome project have foundered in the cash-starved Ministry of Education, Science and Culture (MESC). MESC will set aside a small amount of money this fiscal year to establish the first division of a new human genome analysis centre at Tokyo University's Institute of Medical Science and grants for genome research will be increased. But the sums of money involved are considerably less than the modest amount scientists were hoping for. Failure to launch a large-scale project is likely to lead to renewed US criticism of Japan's failure to contribute sufficiently to the international effort to map and sequence the human genome.

Last summer, five MESC subcommittees of nearly 70 scientists led by Kenchi Matsubura of Osaka University compiled a report proposing that over $¥ 6,000$ million ( $\$ 45$ million) be spent on a five-year project. But, even before the report was printed in October, MESC officials trimmed the proposal down in budget requests for 1991 submitted at the end of August. Now those requests have been further slashed in end-of-year negotiations with the Ministry of Finance.

The report recommended spending $¥ 5,000$ million for research grants and $¥ 650$ million to create 35 new posts for genome research at about five research institutes and universities around the country over a five-year period. It also proposed setting up the new human genome analysis centre at Tokyo University over the same five-year period with 36 new researchers in eight divisions.

But in MESC's budget request, only $¥ 500$ million was allocated for grants in 1991 , half the average annual amount suggested. This has been further reduced to $¥ 400$ million during finalization of the budget, according to some of the scientists involved in compiling the October report.

Only two new posts will be created around the country each year rather than the seven suggested. And the number of divisions at the new centre at Tokyo University has been cut from eight to three.

The first, the 'genome data base division', will open this year with four researchers - a professor, an associate professor, a research assistant and a technician. But, although MESC scientists were hoping to get about $¥ 100$ million for facilities for the new division, a professor at the institute says that they have been told they cannot expect more than "1020 per cent" of that figure. Furthermore, plans to rent a supercomputer for about $¥ 300$ million a year have been shelved until next year. And the institute has been forced to look for new non-MESC sources of funds to support the new division.
Money is not the only problem for the new centre. The Institute of Medical Science has no biologists with expertise on computing and heated discussions are now under way to decide whom to appoint as professor of the new division, a process which is done behind closed doors rather than through open advertising for applicants.

MESC scientists orginally hoped that the new centre would be established at the National Genetics Institute in Mishima where the small DNA Data Bank of Japan (DDBJ) is located. But some researchers at Mishima opposed the idea because they did not want to get involved in providing DNA analysis services for all of Japan.

MESC is not the only government organization supporting genome research. There are small genome-related research projects supported by the Science and Technology Agency, the Ministry of Health and Welfare and the Ministry of Agriculture, Forestry and Fisheries. But rather than helping the launch of a project, the large number of government organizations involved has probably been a hindrance.

Discussions are now under way between the various ministries and agencies on how to "cut the pie" of genome research, says Kennichi Matsubara. But Japan's only hope for a substantial human genome project now seems to lie with the Ministry of International Trade and Industry (MITI) and private companies.

David Swinbanks

ENVIRONMENTAL RELEASE

\section{Tomatoes approved}

Tokyo

AFTER a tortuous bureaucratic process, Japan's Ministry of Agriculture, Forestry and Fisheries (MAFF) last week approved Japan's first release of a genetically engineered organism into the open environment.

This month the ministry's National Institute of Agro-Environmental Sciences in Tsukuba will begin field experiments with tomato plants that have been genetically engineered to resist tobacco mosaic virus. The tomato plants will be grown alongside unaltered plants in open fields surrounded by only a fence and trees to investigate natural pollination and growth of the plants, and their effects on soil bacteria and flora.

Approval was given only after closed experiments had been carried out in the laboratory and greenhouses for over two years under two sets of regulations for the handling of genetically engineered organisms laid down by MAFF and the Science and Technology Agency. David Swinbanks

\section{Polytechnics seeking their fair share}

\section{London}

RESEARCHERS at Britain's 32 polytechnics are disappointed that this year's budget for the research councils (see page 359) has not been increased by the planned transfer of $£ 50-£ 100$ million from the budget of the Universities Funding Council (UFC). That transfer of funds, intended to cover overhead costs, has now been delayed until 1992-93 (see Nature 348, 183; 15 November 1990).

The transfer will help redress the imbalance of research support for the two sectors of British higher education. But many in the polytechnics now say that wholesale reform of British research support is needed if they are to compete on even terms for research council grants.

Under the traditional British 'dualsupport' system, some $£ 800$ million of UFC spending on the universities (about one-third of UFC's annual budget) is reckoned to underpin research, financed by more than $£ 200$ million a year in direct grants from the research councils. By contrast, the polytechnics' $£ 6.7$ million research council income in 1988-89 was supported by $£ 30$ million provided separately from recurrent costs by the Polytechnics and Colleges Funding Council (PCFC). (Last year, a PCFCappointed committee recommended that polytechnic research spending should be increased to $£ 58$ million in 1991-92 - see Nature 347, 217; 1990.)

The planned transfer, suggested by the Department of Education and Science last year, would also make the research councils responsible for the overhead costs of research - equipment maintenance, library costs and the like (Nature $\mathbf{3 4 3}, \mathbf{1 9 9}$; 1990 ). But difficulties in identifying these costs have delayed the transfer by a year; the research councils and the Committee of Vice-Chancellors and Principals (CVCP) now plan to produce a detailed cost-analysis for a sample of university research projects.

The transfer of UFC funds to the research councils was designed to improve the management of public research spending in universities rather than to help the polytechnics. One difficulty is that the estimate that one third of UFC spending supports research is notional only, that it includes a substantial salary element and that much of this may now be less applicable to research than in the past, given the general pressure on university budgets.

Terence Burlin, rector of the Polytechnic of Central London, nevertheless argues strongly that the vast majority 